\title{
Management of Dollar Spot on Creeping Bentgrass with Metabolites of Pseudomonas aureofaciens (TX-1)
}

J. F. Powell and J. M. Vargas, Jr., Department of Botany and Plant Pathology, Michigan State University, East Lansing 48824; M. G. Nair, Department of Horticulture and National Food Safety and Toxicology Center, Michigan State University, East Lansing 48824; A. R. Detweiler, Department of Botany and Plant Pathology, Michigan State University, East Lansing 48824; and A. Chandra, Nutraceutical International Corporation, Ogden, UT 84401

\begin{abstract}
Powell, J. F., Vargas, J. M., Jr., Nair, M. G., Detweiler, A. R., and Chandra, A. 2000. Management of dollar spot on creeping bentgrass with metabolites of Pseudomonas aureofaciens (TX1). Plant Dis. 84:19-24.

Antifungal extracts from four strains of bacteria that were selected for their ability to inhibit fungal turfgrass pathogens were compared for in vitro activity. The cell extract from Pseudomonas aureofaciens Tx-1 (ATCC 55670) exhibited the greatest antifungal activity against selected turfgrass pathogens. Purification of the extract yielded a single active component that was identified as phenazine-1 carboxylic acid (PCA). Minimum inhibitory concentrations of PCA to tested fungal pathogens ranged from 10 to $25 \mu \mathrm{g} / \mathrm{ml}$. In greenhouse studies, PCA provided management of dollar spot on creeping bentgrass equal to that of the commercial fungicides triadimefon and chlorothalonil at equivalent rates of active ingredient. Phytotoxic effects were observed on creeping bentgrass in greenhouse but not field evaluations of PCA at the rate of $0.48 \mathrm{~g} / \mathrm{m}^{2}$. At the end of 2 years of field study, PCA applied every 14 days at $0.15 \mathrm{~g} / \mathrm{m}^{2}$ provided dollar spot management on creeping bentgrass equal to that of chlorothalonil applied every 10 days at the label rate of $0.48 \mathrm{~g} / \mathrm{m}^{2}$.
\end{abstract}

Dollar spot, caused by Sclerotinia homoeocarpa, is a major disease of turfgrasses throughout the world and is considered the most economically significant turfgrass disease in the United States and Canada $(9,25)$. On golf course putting greens and fairways, symptoms of dollar spot appear as bleached or straw-colored spots up to $5 \mathrm{~cm}$ in diameter. Under high disease pressure, these spots may coalesce to form larger irregular patches.

Management of dollar spot and other fungal turfgrass diseases is highly dependent on the application of chemical fungicides. The development of resistance of $S$. homoeocarpa to the benzimidazole (26), dicarboximide (4), and demethylase inhibitor (8) classes of chemical fungicides, and the failure of agrochemical companies to re-register some chemical fungicides with the EPA due to environmental concerns, have promoted research into identification of novel chemical fungicides as well as alternative disease management strategies. Investigations of alternative tools for the management of dollar spot include the use of composts (18) and biological control agents $(9,11,17)$. Disease

Corresponding authors: J. F. Powell and J. M. Vargas, Jr.; E-mail: powelljo@pilot.msu.edu

Accepted for publication 5 September 1999.

Publication no. D-1999-1026-01R

(C) 2000 The American Phytopathological Society management by biological control agents in vitro and in natural environments is often attributed to the production of diffusible metabolites by the biological control agent. These diffusible metabolites include enzymes, siderophores, hydrogen cyanide, ethylene, and antibiotics (6).

Natural antifungal products, including validomycin A (13) and Kasugamycin (24), have received interest for commercial development (7). More frequently, natural products serve as precursors from which analogs are developed with better physical properties and increased bioactivity. Natural products receiving attention in this area include pyrrolnitrin $(14,19)$, hadacidin (5), thiolutin (3), and $\beta$-methoxyacrylates (1), which gave rise to strobilurin analogs (28).

The purpose of this study was to compare the activity of antifungal metabolites produced by bacteria showing strong antibiosis activity in vitro. One of these metabolites, phenazine carboxylic acid (PCA), was selected for evaluation of $S$. homoeocarpa management under in vitro, greenhouse, and field conditions.

\section{MATERIALS AND METHODS}

Four bacterial strains were chosen for this study based on preliminary in vitro antibiosis activity toward the selected fungal turfgrass pathogens. Bacillus pumilus (VI-6-S) and Pseudomonas aureofaciens (IV-7-T) were isolated from the thatch and soil of Kentucky bluegrass recovering from necrotic ring spot in East Lansing, Michigan (16). P. aureofaciens (Tx-1; ATCC
55670) and $P$. aureofaciens (Tx-2) were isolated from the thatch of a creeping bentgrass sample received from Texas for diagnosis at Michigan State University. Isolate identification was performed by fatty acid analysis (Microcheck, Inc., Northfield, VT) and carbon source oxidation with GN MicroPlates (Biolog, Inc., Hayward, CA). Bacteria were cultured in $100 \mathrm{ml}$ of YMG broth $(0.4 \mathrm{~g}$ of yeast extract, $1.0 \mathrm{~g}$ of malt extract, and $0.4 \mathrm{~g}$ of anhydrous dextrose per $100 \mathrm{ml}$ of distilled water) in 500-ml Erlenmeyer flasks and incubated 7 days on a rotary shaker at $100 \mathrm{rpm}$ in the dark at $26^{\circ} \mathrm{C}$.

Extraction. The bacterial cell mass was separated from the broth by centrifugation at $10,000 \mathrm{rpm}$ at $4^{\circ} \mathrm{C}$ for $15 \mathrm{~min}$. The cell mass was homogenized with $100 \mathrm{ml}$ of methanol:chloroform (4:1) and filtered. Insoluble cell mass was discarded, and the methanol:chloroform extract was evaporated to dryness by rotary evaporation at $40^{\circ} \mathrm{C}$ and dried in a desiccator for $24 \mathrm{~h}$. The cell-free broth was lyophilized for 24 $\mathrm{h}$ at $5^{\circ} \mathrm{C}$, and the dried powder was extracted with $100 \mathrm{ml}$ of methanol. Methanol-insoluble residue and the methanolsoluble fractions were dried overnight in a desiccator.

Bioassays. Extracts and purified fractions from each of the bacterial strains were assayed for antibiosis against Bipolaris sorokiniana, Magnaporthe poae, and Sclerotinia homoeocarpa. Potato dextrose agar (PDA) (39 g/liter; Difco, Detroit, MI) plates were inoculated with either 1,000 spores of B. sorokiniana or with $0.1 \mathrm{ml}$ of $M$. poae or $S$. homoeocarpa mycelial suspension. These were prepared by culturing M. poae or $S$. homoeocarpa in $100 \mathrm{ml}$ of potato dextrose broth ( $24 \mathrm{~g} /$ liter; Difco) for 5 days. Mycelial mats were shredded by a Kinematica (Kinematica, Inc., Cincinnati, $\mathrm{OH})$ tissue grinder for $20 \mathrm{~s}$. Bacterial culture extracts and purified fractions were dissolved in dimethyl sulfoxide (DMSO) and applied to the plates in $25-\mu \mathrm{l}$ aliquots to deliver 250,100 , and $50 \mu \mathrm{g}$ of extract or purified fractions. Bioassay plates were replicated three times for each extract concentration and fungal strain combination. Following incubation at $28^{\circ} \mathrm{C}$ for 3 days, zones of inhibition were recorded in millimeters. Data were analyzed using Tukey's test to separate mean zone of inhibition diameters within fungal test strains and extract concentrations. 
Large-scale production of PCA. Large-scale preparation of PCA was conducted by culturing $P$. aureofaciens in a Biostat Model 100D bioreactor (Braun Instruments, Bulingame, CA). Bacteria were grown in 100 liters of A9 medium (5 $\mathrm{g}$ of Bacto peptone, $10 \mathrm{~g}$ of anhydrous dextrose, and $20 \mathrm{~g}$ of Brer Rabbit Dark Molasses per liter) at $26^{\circ} \mathrm{C}$ for $66 \mathrm{~h}$. The cell mass was collected through a Sharples Model As-12 (Sharples Company, Philadelphia, PA) continuous flow centrifuge at a rate of 1 liter/min and stored at $-20^{\circ} \mathrm{C}$ until extraction. The cells were homogenized with $500 \mathrm{ml}$ of chloroform for 10 min, and the insoluble cell debris was removed through filtration using a $600-\mathrm{ml}$ (10 to $15 \AA$ ) fritted funnel. The insoluble cell cake was rinsed twice with $200 \mathrm{ml}$ of chloroform. The combined chloroform extracts were evaporated to dryness by rotary evaporation. Alternatively, PCA was recovered from the whole broth from the 100-liter bioreactor by extracting 2-liter aliquots of broth with 1 liter of chloroform in a 4-liter separatory funnel. The chloroform extract was evaporated to dryness by rotary evaporation to yield an extract containing PCA.

The extract containing PCA was fractionated by vacuum liquid chromatography (VLC) on silica gel (250 g, Analtech, $60 \AA$ pore, 35 to $75 \mu \mathrm{m}$ particle size). Prior to the fractionation, the silica gel was packed in a $600-\mathrm{ml}(10$ to $15 \AA$ ) fritted funnel and conditioned with $500 \mathrm{ml}$ of hexane:acetone (1:1). Ten grams of the crude extract was stirred with $200 \mathrm{ml}$ of hexane:acetone (1:1) and loaded onto the column. One liter of hexane:acetone (1:1) was eluted through the column and discarded. The active fraction was eluted from the column with 2 liters of chloroform:methanol (4:1), and the solvent was removed from this fraction by rotary evaporation followed by drying under vacuum in a desiccator for $30 \mathrm{~min}$.

Thin-layer chromatography (TLC) revealed that this fraction contained one major active compound. Therefore, it was crystallized by first dissolving the fraction in a minimal volume of chloroform with mild heating in hot air. Crystal formation was initiated with the addition of methanol and promoted by cooling the solution at $-4^{\circ} \mathrm{C}$ for $24 \mathrm{~h}$. The yellow needle-shaped crystals were recovered by filtration with a fritted funnel (4.5 to $5 \AA$ ), dried under vacuum in a desiccator, and stored at $-4^{\circ} \mathrm{C}$. The crystals were characterized by $\mathrm{H}^{1}$ - and ${ }^{13} \mathrm{C}$ NMR spectral experiments. The $\mathrm{R}_{\mathrm{f}}$ value of the crystals from TLC analysis with chloroform:acetone (4:1) was compared with the $\mathrm{R}_{\mathrm{f}}$ values of antifungal metabolites reported from $P$. aureofaciens (6). Finally, the crystalline compound was compared by TLC with an authentic sample of PCA provided by D. M. Weller (Washington State University, Pullman).

Minimum inhibitory concentration (MIC) of PCA to completely inhibit the growth of selected turfgrass pathogens. PCA crystals were dissolved in DMSO to yield a $10,000 \mu \mathrm{g} / \mathrm{ml}$ solution. This solution was amended to $100 \mathrm{ml}$ of PDA to yield a total of $1 \%$ DMSO and deliver PCA concentrations of $0.1,10,25,50$, and $100 \mu \mathrm{g} / \mathrm{ml}$. Control plates had 1\% DMSO alone. MIC plates also were prepared for commercial fungicides to compare antifungal activity. Commercial fungicides included triadimefon (1-(4-chlorophenoxy)3,3-dimethyl-1-(1H-1,2,4-triazole-1-yl)-2butanone) in the form of Bayleton 25 WDG (Bayer Corp., Kansas City, MO) and chlorothalonil (tetrachloroisophthalonitrile) in the form of Daconil 2787 F (ISK Biotech, Mentor, $\mathrm{OH})$. The commercial fungicides were dissolved in sterile water and amended with PDA to provide active ingredient concentrations of $0.1,10,25,50$, and $100 \mu \mathrm{g} / \mathrm{ml}$.

Turfgrass pathogens assayed included an isolate of $S$. homoeocarpa sensitive to demethylase inhibitor fungicides $\left(\mathrm{DMI}^{\mathrm{s}}\right)$, an isolate of $S$. homoeocarpa resistant to demethylase inhibitor fungicides $\left(\mathrm{DMI}^{\mathrm{r}}\right)$ (4), M. poae (ATCC 66441), Leptosphaeria korrae, Gaeumannomyces graminis, Typhula incarnata, Microdochium nivale, Bipolaris sorokiniana, Rhizoctonia solani, and Colletotrichum graminicola. Pathogens were grown at $22^{\circ} \mathrm{C}$, except for T. incarnata, which was grown at $4^{\circ} \mathrm{C}$. Each pathogen-amended PDA combination was performed with three replicates, and the study was conducted twice. Measurements of fungal growth were taken when the fungal mycelium in the control treatments approached the outer edge of the plate. Resulting measurements of radial growth were divided by the average radial growth of control plates to yield a percent- age of control. The data were recorded as the average relative growth. Measurements were taken after 2 days of incubation for $S$. homoeocarpa $\left(\mathrm{DMI}^{\mathrm{s}}\right), \quad S$. homoeocarpa $\left(\mathrm{DMI}^{\mathrm{r}}\right)$, and $R$. solani, 5 days for $C$. graminicola and $M$. nivale, 7 days for $B$. sorokiniana and $M$. poae, 10 days for $L$. korrae and G. graminis, and 14 days for $T$. incarnata.

Greenhouse evaluation of PCA for management of dollar spot and phytotoxicity. Greenhouse evaluation of PCA as a fungicidal treatment was conducted on 2month-old Penncross creeping bentgrass (Agrostis palustris) maintained at a height of $0.5 \mathrm{~cm}$. Turf was grown in Styrofoam cups $(9.1 \mathrm{~cm}$ diameter) and fertilized every 2 weeks with Peters N-P-K (20-20-20) to provide a rate of $24.4 \mathrm{~kg} \mathrm{~N} / \mathrm{ha}$. Greenhouse studies were set up as randomized block designs with four replicates and were conducted twice.

Treatments were applied as a foliar spray of $2 \mathrm{ml}$ per cup through an atomizer attached to an air line. PCA treatments were prepared by dissolving $0.1 \mathrm{~g}$ of PCA in $7 \mathrm{ml}$ of hexane:acetone (1:1) containing Tween 80 (polyxyethylene sorbitan monooleate, $2 \%$ ) as an emulsifying agent. PCA was applied at rates of 0.077 and $0.48 \mathrm{~g}$ a.i. $/ \mathrm{m}^{2}$, respectively, to correspond to the active ingredients of the triadimefon and chlorothalonil. Two fungicide controls were included in this study as representatives of systemic and contact fungicides. The systemic fungicide used in this study was triadimefon in the commercial form of Bayleton 25 WDG and was used at the rate of $31.8 \mathrm{~g} / 100 \mathrm{~m}^{2}\left(0.077 \mathrm{~g}\right.$ a.i. $\left./ \mathrm{m}^{2}\right)$. The contact fungicide chlorothalonil was used in the commercially available form as Daconil 2787 Flowable at the lowest label rate of $95.5 \mathrm{ml} / 100 \mathrm{~m}^{2}\left(0.48 \mathrm{~g}\right.$ a.i. $\left./ \mathrm{m}^{2}\right)$.

Two separate experiments were conducted: one to examine phytotoxicity and a second to examine disease management. The phytotoxicity experiment was conducted by treating the turf with PCA and the representative fungicides followed by a rating 7 days after initial treatment. Phytotoxicity was scored on a 10 to 0 scale on foliar symptoms, with 10 being $100 \%$ healthy turf and 0 being 100\% dead. Data were analyzed using Tukey's test.

Disease management greenhouse experiments were set up in the same format

Table 1. Zones of inhibition $(\mathrm{mm})$ from cell extracts $(\mu \mathrm{g} / \mathrm{ml})$ of bacterial isolates against Bipolaris sorokiniana, Sclerotinia homoeocarpa, and Magnaporthe poae

\begin{tabular}{|c|c|c|c|c|c|c|c|c|c|}
\hline \multirow[b]{2}{*}{ Isolate } & \multicolumn{3}{|c|}{ B. sorokiniana } & \multicolumn{3}{|c|}{ S. homoeocarpa } & \multicolumn{3}{|c|}{ M. poae } \\
\hline & $250^{x}$ & 100 & 50 & 250 & 100 & 50 & 250 & 100 & 50 \\
\hline Tx-1 & $23^{y} a^{z}$ & $23 \mathrm{a}$ & $21 \mathrm{a}$ & $44 \mathrm{a}$ & $32 \mathrm{a}$ & $28 \mathrm{a}$ & $24 \mathrm{ab}$ & $20 \mathrm{~b}$ & $14 \mathrm{~b}$ \\
\hline Tx-2 & $22 \mathrm{a}$ & $21 \mathrm{a}$ & $16 \mathrm{~b}$ & $38 \mathrm{~b}$ & $22 \mathrm{~b}$ & $16 \mathrm{~b}$ & $28 \mathrm{~b}$ & $28 \mathrm{a}$ & $20 \mathrm{a}$ \\
\hline VI-6-S & $16 \mathrm{~b}$ & $12 \mathrm{~b}$ & $8 \mathrm{c}$ & $16 \mathrm{c}$ & $12 \mathrm{c}$ & $10 \mathrm{c}$ & $20 \mathrm{a}$ & $20 \mathrm{~b}$ & $16 \mathrm{~b}$ \\
\hline IV-7-T & $16 \mathrm{~b}$ & $10 \mathrm{~b}$ & $9 \mathrm{c}$ & $17 \mathrm{c}$ & $14 \mathrm{c}$ & $10 \mathrm{c}$ & $22 \mathrm{ab}$ & $20 \mathrm{~b}$ & $16 \mathrm{~b}$ \\
\hline
\end{tabular}

${ }^{\mathrm{x}}$ Concentrations listed as $\mu \mathrm{g} / \mathrm{ml}$.

y Diameter of zone of inhibition recorded in millimeters.

${ }^{\mathrm{z}}$ Treatments followed by the same letter in a column are not significantly different. Data analyzed with Tukey's test at $P=0.05$. 
as the phytotoxicity experiment; however, the cups were inoculated with S. homoeocarpa. Inoculation of turf was carried out $24 \mathrm{~h}$ after treatment application to allow for evaporation of solvents. S. homoeocarpa inoculum was prepared by autoclaving $250 \mathrm{~g}$ of wheat seeds with $250 \mathrm{ml}$ of nutrient broth ( $8 \mathrm{~g} /$ liter; Difco) for 30 min in a 2-liter Erlenmeyer flask. Ten plugs of S. homoeocarpa were transferred to the wheat seed medium, and the culture was incubated at $26^{\circ} \mathrm{C}$ for 2 weeks, during which the culture was shaken daily. Inoculations were performed by placing 10 infested wheat seeds on the surface of the turf. Cups were incubated in a humidity chamber in the greenhouse and misted daily with a spray bottle. On the fourth day of incubation, cups were removed from the humidity chamber and wheat seeds were removed. Disease ratings were taken 4 days after the inoculum was removed and scored as a percentage of the area of grass per cup showing disease symptoms. Means were separated by Tukey's test.

Field evaluation of PCA for the management of dollar spot. Dollar spot field studies were conducted at the Hancock Turfgrass Research Center (Lansing, MI) on a 10-year-old stand of Emerald creeping bentgrass. Fertility was maintained at a rate of $24.4 \mathrm{~kg} \mathrm{~N} / \mathrm{ha} / \mathrm{month}$. Plots were mowed three times a week to a height of $4.76 \mathrm{~mm}$ and received $2.54 \mathrm{~mm}$ of water daily. This sward exhibited natural infestation with $S$. homoeocarpa. Field studies were designed with four replicates of randomized complete blocks of $0.9 \times 1.2 \mathrm{~m}$ plots.

The first-year study was initiated on 30 July 1992. Treatments included an untreated control, triadimefon (Bayleton 25) at a rate of $0.15 \mathrm{~g}$ a.i. $/ \mathrm{m}^{2}$, and a PCA-containing crude extract to deliver PCA at 0.15 $\mathrm{g}$ a.i. $/ \mathrm{m}^{2}$. Triadimefon and PCA treatments were applied at 14-day intervals. The PCA-containing extract was dissolved in $50 \mathrm{ml}$ of DMSO before being added to 200 $\mathrm{ml}$ of tap water for spray application to a single plot with a $\mathrm{CO}_{2}$ hand sprayer.

The second-year study was initiated on 27 July 1993 and continued until mid-October. The systemic fungicide triadimefon was applied at the rate of $0.08 \mathrm{~g}$ a.i. $/ \mathrm{m}^{2}$ (21-day interval), and at the $0.15 \mathrm{~g}$ a.i. $/ \mathrm{m}^{2}$ (14-day interval) rate used in the 1992 study. Chlorothalonil was applied at 10-day intervals at $0.48 \mathrm{~g}$ a.i. $/ \mathrm{m}^{2}$ and at one-third the label rate of $0.16 \mathrm{~g}$ a.i. $/ \mathrm{m}^{2}$. PCA applications were made using crude cell extract. The percentage of PCA in the crude cell extract was determined from the yield of pure PCA from a known amount of crude extract. PCA was applied at 0.08, 0.15, 0.16 , and $0.48 \mathrm{~g}$ a.i. $/ \mathrm{m}^{2}$ at the intervals of $21,14,10$, and 10 days, respectively. A formulation of hexane:acetone (1:1) with $1 \%$ Tween 80 (polyoxyethylene sorbitan monooleate) was used in the first 3 weeks of the study. This formulation did not maintain extract in emulsion when prepared for the $0.48 \mathrm{~g}$ a.i. $/ \mathrm{m}^{2}$ rate of application. The formulation of the crude cell extract was modified to hexane:acetone (1:1) amended with $2 \%$ Tween 80 . Ten $\mathrm{ml}$ of the hexane:acetone-Tween 80 solvent was applied per plot. In the 1992 preliminary study, DMSO was used as a solvent for the Tx-1 antibiotic; however, a solvent control treatment was not included. DMSO was included as a treatment in the 1993 study and was applied to deliver the same rate over 14-day intervals.

Disease ratings were conducted on a weekly basis throughout the course of both studies. Ratings were taken by counting individual dollar spots per plot. Due to greater variation in plots with higher disease incidence than in those at lower disease levels, data distribution was normalized as the log of the number of spots +1 . Seasonal data were consolidated into area under disease progress curves (AUDPC). Means were separated with Tukey's honestly significant range test $(P=0.05)$ using the MSTATC version 2.01 statistical analysis software (Department of Crop and Soils, Michigan State University, East Lansing).

\section{RESULTS}

Zone of inhibition data for extracts from the four bacterial strains varied (Table 1). The cell extracts were the only fractions that exhibited antifungal activity for each of the antagonistic bacterial strains examined. Cell extract from Tx-1 produced the largest zones of inhibition to B. sorokiniana and $S$. homoeocarpa, whereas the cell extract of Tx-2 yielded the largest zones of inhibition to $M$. poae. Cell extracts of VI6-S and IV-7-T produced zones of inhibition smaller than those of Tx-1 and Tx-2. Therefore, $P$. aureofaciens Tx-1 was selected for further study due to its greater antifungal activity.

Large-scale production of PCA. Recovery of cell mass from 100-liter cultures yielded $960 \mathrm{~g}$ of wet cell mass. Extraction of the cell mass or whole broth with chloroform provided $109 \mathrm{~g}$ of crude active extract. Further fractionation of this extract by VLC was conducted on 10-g batches of crude extract. The hexane:acetone (1:1) fraction recovered by VLC yielded a greenish gum when the solvent was removed by rotary evaporation. This fraction did not exhibit any antifungal properties. Of the $10 \mathrm{~g}$ of crude extract, $5.4 \mathrm{~g}$ of active product, PCA, was recovered in the chloroform:methanol (4:1) VLC fraction. Further purification of this fraction yielded crystals that were identical to an authentic sample of PCA crystals with respect to color, shape, and $\mathrm{R}_{\mathrm{f}}$ values. Further $\mathrm{H}^{1}$ - and ${ }^{13} \mathrm{C}$ NMR spectroscopic experiments confirmed that the component in the active fraction responsible for fungal growth inhibition was PCA.

Minimum inhibitory concentration (MIC) of PCA to completely inhibit the growth of selected turfgrass pathogens. MIC values for PCA, chlorothalonil, and triadimefon are provided in Table 2. PCA yielded MICs of less than $100 \mu \mathrm{g} / \mathrm{ml}$ for all test pathogens except $M$. nivale and $R$. solani. MIC values for PCA generally ranged from 10 to $50 \mu \mathrm{g} / \mathrm{ml}$. However, even at concentrations less than the MIC, test organisms exhibited reduced growth. $B$. sorokiniana spores plated on 0.1 - and $1.0-\mu \mathrm{g} / \mathrm{ml}$ concentrations of PCA exhibited increased sporulation in comparison with untreated control plates. MIC values of PCA were lower than or equal to chlorothalonil or triadimefon against $B$. sorokiniana, C. graminicola, G. graminis, L. korrae, and M. poae. In comparison with chlorothalonil, PCA produced greater inhibitory activity against $C$. graminicola, G. graminis, L. korrae, M. poae, S. homoeocarpa $\left(\mathrm{DMI}^{\mathrm{S}}\right)$, and S. homoeocarpa $\left(\mathrm{DMI}^{\mathrm{r}}\right)$. In comparison with triadimefon, PCA exhibited lower MICs against $B$. sorokiniana, C. graminicola, L. korrae, and $M$. poae. PCA, chlorothalonil, and triadimefon failed to completely inhibit the growth of $M$. nivale at a concentration of $100 \mu \mathrm{g} / \mathrm{ml}$.

Greenhouse evaluation of PCA for the management of dollar spot and phytotoxicity. Spray application of PCA at the rate of $0.48 \mathrm{~g}$ a.i. $/ \mathrm{m}^{2}$ resulted in slight discoloration of plant foliage. Discoloration

Table 2. Minimum inhibitory concentrations $(\mu \mathrm{g} / \mathrm{ml})$ for phenazine carboxylic acid (PCA), chlorothalonil, and triadimefon for a variety of fungal turfgrass pathogens tested

\begin{tabular}{lccc}
\hline Fungal pathogen & PCA & Chlorothalonil & Triadimefon \\
\hline Bipolaris sorokiniana & $10>25^{\mathrm{y}}$ & $10>25$ & $>100$ \\
Colletotrichum graminicola & $10>25$ & $50>100$ & $25>50$ \\
Gaeumannomyces graminis & $1>10$ & $50>100$ & $50>100$ \\
Leptosphaeria korrae & $10>25$ & $>100$ & $>100$ \\
Magnaporthe poae & $10>25$ & $50>100$ & $50>100$ \\
Microdochium nivale & $>100$ & $>100$ & $>100$ \\
Rhizoctonia solani & $>100$ & $>100$ & $10>25$ \\
Sclerotinia homoeocarpa $\left(\mathrm{DMI}^{\mathrm{s}}\right)^{\mathrm{z}}$ & $25>50$ & $50>100$ & $1>10$ \\
S. homoeocarpa $\left(\mathrm{DMI} \mathrm{I}^{\mathrm{r}}\right)$ & $25>50$ & $1>10$ & $10>25$ \\
Typhula incarnata & $10>25$ & $10>25$ \\
\hline
\end{tabular}

y Concentration $(\mu \mathrm{g} / \mathrm{ml})$ required to completely inhibit fungal growth on amended potato dextrose agar.

${ }^{\mathrm{z}} \mathrm{S}=$ isolate sensitive to demethylase inhibitor (DMI) fungicides. $\mathrm{r}=$ isolate resistant to DMI fungicides. 
was less noticeable for turf treated with $0.15 \mathrm{~g}$ a.i. $/ \mathrm{m}^{2}$ of PCA. Two days following inoculation of turf with $S$. homoeocarpa, aerial mycelial growth was evident. Treatments of triadimefon, chlorothalonil, and the $0.48 \mathrm{~g}$ a.i. $/ \mathrm{m}^{2}$ rate of PCA did not inhibit mycelial growth from the wheat seed inoculum. Average percent infections for each treatment from the first trial, which were not different from those of the second trial (data not shown), are shown in Table 3. PCA provided disease management equal to that of the commercial fungicides at both rates examined (Table 3). Application of solvent alone had no effect on disease.

PCA was phytotoxic at high rates (Table 3). At the $0.48 \mathrm{~g}$ a.i. $/ \mathrm{m}^{2}$ rate, $\mathrm{PCA}$ reduced turf quality with respect to the untreated control and was evident after 4 days. Phytotoxicity was observed as the development of a water-soaked appearance on older foliage, which later turned brown. Foliar damage approached $30 \%$. Newer growth was not affected and continued to grow during the course of this study. PCA at the $0.077 \mathrm{~g}$ a.i. $/ 100 \mathrm{~m}^{2}$ rate did not show additional phytotoxicity to that observed with the solvent alone.

Field evaluation of PCA for the management of dollar spot. In the 1992 preliminary study, disease was not active until 26 August, and disease pressure abated after the 11 September rating date (Table 4). Formulation of PCA using DMSO as a solvent was problematic, because a portion of PCA precipitated when the solution was mixed with water. Agitation of the spray bottle helped to maintain a suspension. The amount of PCA retained in the spray bottle was not recorded. Data for the effect of DMSO as a treatment are not available for the 1992 field study. Inclusion of DMSO in the 1993 study demonstrated that DMSO did not have any effect on dollar spot activity. PCA did not provide disease management equal to that of triadimefon. However, dollar spot management with

Table 3. Greenhouse experiments on dollar spot management efficacy and phytotoxicity for phenazine carboxylic acid (PCA), triadimefon, and chlorothalonil

\begin{tabular}{|c|c|c|c|c|c|}
\hline \multirow[b]{2}{*}{ Treatment } & \multirow[b]{2}{*}{ Application rate } & \multicolumn{2}{|c|}{ Disease ratings } & \multicolumn{2}{|c|}{ Phytotoxicity } \\
\hline & & $\begin{array}{l}\text { Percent } \\
\text { infection }\end{array}$ & $\begin{array}{c}\text { Tukey's } \\
\text { test }\end{array}$ & $\begin{array}{l}\text { Quality } \\
\text { ratingy }\end{array}$ & $\begin{array}{c}\text { Tukey's } \\
\text { test }\end{array}$ \\
\hline Control & & 35.0 & $a^{\mathrm{z}}$ & 10.0 & $\mathrm{a}$ \\
\hline PCA & $0.15 \mathrm{~g}$ a.i. $/ \mathrm{m}^{2}$ & 1.8 & $\mathrm{~b}$ & 9.3 & $\mathrm{~b}$ \\
\hline PCA & $0.48 \mathrm{~g}$ a.i. $/ \mathrm{m}^{2}$ & 0.0 & $\mathrm{~b}$ & 7.3 & $\mathrm{c}$ \\
\hline Triadimefon & $0.15 \mathrm{~g}$ a.i. $/ \mathrm{m}^{2}$ & 0.0 & $\mathrm{~b}$ & 9.8 & $a b$ \\
\hline Chlorothalonil & $0.48 \mathrm{~g}$ a.i. $/ \mathrm{m}^{2}$ & 0.0 & $\mathrm{~b}$ & 10.0 & $\mathrm{a}$ \\
\hline $1: 1$ hexane:acetone & $40 \mathrm{ml} / \mathrm{m}^{2}$ & 23.8 & $\mathrm{a}$ & 9.8 & $a b$ \\
\hline
\end{tabular}

${ }^{\mathrm{y}}$ Taken on 0 to 10 scale $(0=$ completely dead turf, $10=$ healthy turf $)$.

${ }^{\text {z }}$ Data analyzed with Tukey's tests at $P=0.05$ level.

Table 4. 1992 field evaluation of phenazine carboxylic acid (PCA) for dollar spot management

\begin{tabular}{lcccc}
\hline Treatment & Application rate & AUDPC $^{\mathbf{x}}$ & Normalized AUDPC $^{\mathbf{y}}$ & Tukey's test $^{\mathbf{z}}$ \\
\hline Control & $\ldots$ & 86 & 28.13 & $\mathrm{a}$ \\
PCA & $0.15 \mathrm{~g}$ a.i. $. \mathrm{m}^{2} / 14$ days & 14 & 8.6 & $\mathrm{~b}$ \\
Triadimefon & $0.15 \mathrm{~g}$ a.i. $/ \mathrm{m}^{2} / 14$ days & 0 & 0.0 & $\mathrm{c}$ \\
\hline
\end{tabular}

${ }^{x}$ Area under disease progress curve data based on dollar spot incidence for 1992 field data.

y Data normalized as $\log (\mathrm{n}+1)$ prior to data analysis.

${ }^{\text {z }}$ Data analyzed with Tukey's tests at $P=0.05$ level.

Table 5. 1993 field evaluation of phenazine carboxylic acid (PCA) for the management of dollar spot

\begin{tabular}{lcccc}
\hline Treatment & \multicolumn{1}{c}{ Rate } & AUDPC & $\begin{array}{c}\text { Normalized } \\
\text { AUDPC }^{\mathbf{x}}\end{array}$ & Tukey's test $^{\mathbf{y}}$ \\
\hline Control & $\ldots$ & 3,518 & 98.9 & $\mathrm{a}$ \\
PCA & $0.08 \mathrm{~g} \mathrm{a.i.} / \mathrm{m}^{2} / 21$ days & 2,290 & 80.7 & $\mathrm{abc}$ \\
PCA & $0.15 \mathrm{~g} \mathrm{a.i.} / \mathrm{m}^{2} / 14$ days & 582 & 47.4 & $\mathrm{de}$ \\
PCA & $0.16 \mathrm{~g} \mathrm{a.i.} / \mathrm{m}^{2} / 10$ days & 1,299 & 70.1 & $\mathrm{bcd}$ \\
PCA & $0.48 \mathrm{~g} \mathrm{a.i.} / \mathrm{m}^{2} / 10$ days & 875 & 60.9 & $\mathrm{~cd}$ \\
Triadimefon & $0.08 \mathrm{~g} \mathrm{a.i.} / \mathrm{m}^{2} / 14$ days & 73 & 11.8 & $\mathrm{f}$ \\
Triadimefon & $0.15 \mathrm{~g} \mathrm{a.i.} / \mathrm{m}^{2} / 21$ days & 0 & 0.0 & $\mathrm{f}$ \\
Chlorothalonil & $0.16 \mathrm{~g} \mathrm{a.i.} / \mathrm{m}^{2} / 10$ days & 1,104 & 63.9 & $\mathrm{~cd}$ \\
Chlorothalonil & $0.48 \mathrm{~g} \mathrm{a.i.} / \mathrm{m}^{2} / 10$ days & 172 & 26.5 & $\mathrm{ef}$ \\
Solvent & $7.5 \mathrm{ml} / \mathrm{m}^{2} / 10$ days & 1,943 & 82.9 & $\mathrm{abc}$ \\
Solvent & $7.5 \mathrm{ml} / \mathrm{m}^{2} / 14$ days & 2,965 & 91.7 & $\mathrm{ab}$ \\
DMSO & $6.5 \mathrm{ml} / \mathrm{m}^{2} / 14$ days & 2,094 & 87.5 & $\mathrm{abc}$ \\
\hline
\end{tabular}

\footnotetext{
${ }^{\mathrm{w}}$ Area under disease progress curve data based on dollar spot incidence for 1993 field data.

${ }^{x}$ Data normalized as $\log (\mathrm{n}+1)$ prior to data analysis.

y Data analyzed with Tukey's tests at $P=0.05$ level.

${ }^{\mathrm{z}}$ Hexane:acetone (1:1).
}

PCA was significantly better than the control treatment.

The 1993 study examined different rates and frequencies of PCA application (Table 5). In 1993, PCA was compared to chlorothalonil at application rates of $0.48 \mathrm{~g}$ a.i. $/ \mathrm{m}^{2}$ (lowest label rate for chlorothalonil) and $0.16 \mathrm{~g}$ a.i. $/ \mathrm{m}^{2}$ at 10 -day intervals. The $0.16 \mathrm{~g}$ a.i. $/ \mathrm{m}^{2}$ rate, one-third of the lowest label rate, was included to examine 10-day application frequencies without concern of phytotoxicity, which was observed at 0.48 $\mathrm{g}$ a.i. $/ \mathrm{m}^{2}$ in greenhouse studies. A $1: 1$ mixture of hexane:acetone was employed to dissolve the PCA extract, and 1\% Tween 80 was added to form an emulsion with distilled water. This formulation failed to maintain the extract in emulsion for the 10day applications, which were formulated together. The first three applications of the 10-day treatments experienced problems with precipitation of PCA. Once the rate of Tween 80 was increased to $2 \%$, no further problems were experienced.

Disease pressure was greater in 1993 than in 1992 (Table 4, Fig. 1). Neither of the modified solvents used to formulate PCA (DMSO in 1992 and hexane:acetone (1:1) with $2 \%$ Tween 80 in 1993) affected disease incidence throughout this study. Application of PCA at $0.15 \mathrm{~g}$ a.i. $/ 100 \mathrm{~m}^{2}$ on a 14-day interval provided dollar spot management equal to the commercially recommended rate of chlorothalonil $(0.48 \mathrm{~g}$ a.i. $/ \mathrm{m}^{2}$ every 10 days). Treatments of PCA on 10- and 21-day intervals failed to provide dollar spot management comparable to commercial fungicides. As expected, chlorothalonil and triadimefon provided effective management of dollar spot when applied at recommended rates.

\section{DISCUSSION}

This study demonstrates that PCA has some potential for the management of turfgrass fungal diseases. PCA inhibited the growth of turfgrass fungal pathogens in in vitro assays at concentrations equal to or less than those required by chlorothalonil or triadimefon. Greenhouse studies demonstrated the efficacy of PCA to manage dollar spot at rates of active ingredient equal to that of the systemic fungicide triadimefon. Finally, PCA provided significantly better management of dollar spot on creeping bentgrass than untreated plots in field trials and was comparable to management provided by chlorothalonil.

PCA is an antibiotic produced by several Pseudomonas spp., including $P$. aeruginosa, $P$. aureofaciens (12), $P$. chlororaphis (23), and P. fluorescens (27). Of these, $P$. aureofaciens and $P$. fluorescens have been implicated in the natural biological control of take-all disease in wheat (2) and take-all patch in turfgrass (20). Genetic studies demonstrated that PCA production is required to maintain the biological control activity for pseudomonads involved in take-all $(15,21)$. In vitro plate assays have 
demonstrated that PCA is antagonistic to a broad range of fungal pathogens (10).

Thomashow et al. (22) demonstrated that PCA could be recovered from wheat seedling roots colonized by fluorescent pseudomonads at levels sufficient to provide significant disease management. Extrapolation of the amount of PCA recovered suggested that significant take-all suppression could be provided at $80 \mathrm{mg}$ of root-associated PCA per hectare compared with $90 \mathrm{~g}$ of the fungicide triadimenol per hectare applied as a seed treatment to achieve take-all management. Comparison of MICs of PCA, the systemic fungicide triadimefon, and the contact fungicide chlorothalonil against turfgrass pathogens revealed that PCA exhibits comparable in vitro antifungal activity to these commercial fungicides.

PCA provided disease management equal to triadimefon and chlorothalonil in greenhouse studies at equal rates of active ingredient. Some phytotoxicity due to PCA was observed in the greenhouse studies at the rate of $0.48 \mathrm{~g}$ a.i. $/ \mathrm{m}^{2}$, which resulted in a loss of up to $30 \%$ of foliage but was con- fined primarily to older plant tissues. However, phytotoxicity was not observed in field application of PCA at the same rate. The discrepancy between the greenhouse and field effects could possibly be explained by the use of different varieties of creeping bentgrass in greenhouse (Penncross) and field (Emerald) experiments. Differences in the age of the plants used may reflect differences in sensitivity, as plants used in the greenhouse study were 2 months old, compared with plants in the field, which had been maintained for several years. Additionally, turf in the field is not as succulent as turf maintained in the greenhouse, where optimal conditions for growth are maintained.

Field evaluation of PCA was conducted over the course of two seasons. Significant disease management was achieved with application of PCA at a rate of $0.15 \mathrm{~g} / \mathrm{m}^{2}$ every 14 days over both field studies. Disease management at this rate was equal to that of chlorothalonil at a comparable rate $\left(0.16 \mathrm{~g} / \mathrm{m}^{2}\right.$; one-third lowest label rate $)$ applied on a 10-day schedule. Disease management was not afforded by PCA

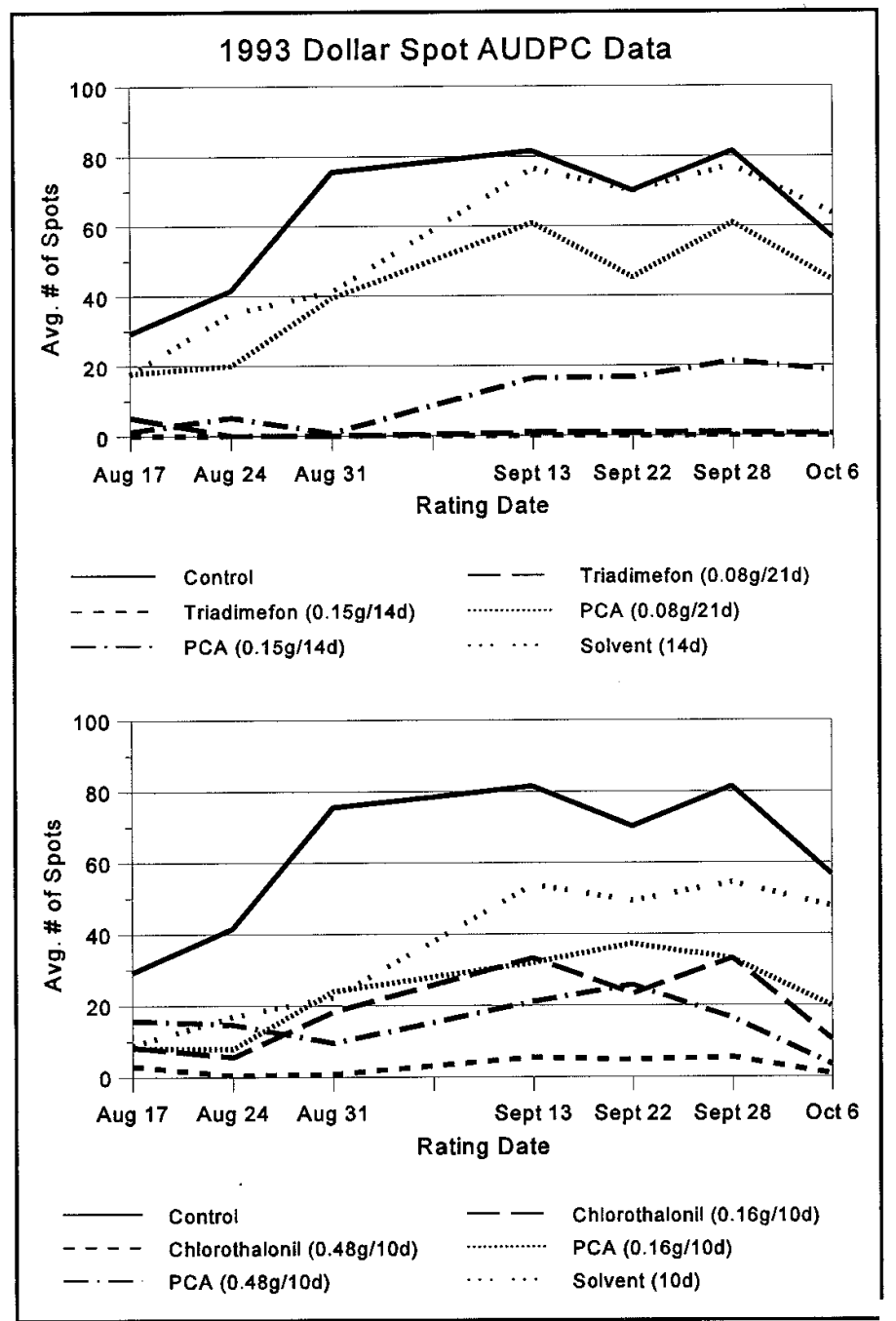

Fig. 1. Area under disease progress curves (AUDPC) for 1993 management of dollar spot with phenazine-1 carboxylic acid (PCA). Treatment rates listed in $\mathrm{g} / \mathrm{m}^{2}$.

over a 21-day schedule, which suggests that it does not have long-term residual effect and may further suggest that PCA does not act in a systemic manner. Inability of the 10-day applications of PCA to provide disease management equal to the 14day treatment in the 1993 field study is attributed to the formulation difficulties experienced over the first month of the study, which accounts for the first third of the 1993 dollar spot field season. Accumulation of disease in this part of the season limited the ability of these treatments to provide significant disease reduction by AUDPC analysis. Disease incidence in the 10-day treatment plots by the end of the season was significantly lower than that of the control treatments at the final rating date. These field evaluations demonstrate that foliar applications of PCA can provide significant dollar spot disease management.

In conclusion, the results of this study demonstrate that PCA exhibits comparable antifungal activity to chlorothalonil and triadimefon in in vitro and greenhouse evaluations. Phenazine-1 carboxylic acid provided dollar spot management in the field comparable to that of chlorothalonil; however, the disease management did not reach that provided by triadimefon.

\section{LITERATURE CITED}

1. Clough, J. M. 1993. The strobilurins, oudemansins, and myxothiazols, fungicides derivatives of $\beta$-methoxyacrylic acid. Nat. Prod. Rep. 565-574.

2. Cook, R. J., and Rovira, A. D. 1976. The role of bacteria in the biological control of Gaeumannomyces graminis by suppressive soils. Soil Biol. Biochem. 8:269-273.

3. Dell, I., Godfrey, C. R. A., and Wadsworth, D. J. 1992. Total synthesis of naturally occurring 1,2-dithiolo[4,3-b]pyrrolones and related compounds. Pages 384-394 in: Synthesis and Chemistry of Agrochemicals III. D. R. Baker, J. G. Fenyes, and J. J. Steffens, eds. ACS Symposium Series No. 504, American Chemical Society, Washington, DC.

4. Detweiler, A. R., Vargas, J. M., Jr., and Danneberger, T. K. 1983. Resistance of Sclerotinia homoeocarpa to iprodione and benomyl. Plant Dis. 67:627-630.

5. Dunn, C. L., and Klein, S. P. 1985. Post-harvest treatment of vines: A new concept in Plasmopara control. Pages 407-410 in: Fungicides for Crop Protection - 100 Years of Progress. I. M. Smith, ed. British Crop Protection Council, Farnham, Eng.

6. Fravel, D. R. 1988. Role of antibiosis in the biocontrol of plant diseases. Annu. Rev. Phytopathol. 26:75-91.

7. Godfrey, C. R. A. 1995. Fungicides and bactericides. Pages 311-340 in: Agrochemicals from Natural Products. C. R. A. Godfrey, ed. Marcel Dekker, New York.

8. Golembiewski, R. C., Vargas, J. M., Jr., Jones, A. L., and Detweiler, A. R. 1995. Detection of demethylation inhibitor (DMI) resistance in Sclerotinia homoeocarpa populations. Plant Dis. 79:491-493.

9. Goodman, D. M., and Burpee, L. L. 1991. Biological control of dollar spot disease of creeping bentgrass. Phytopathology 81:14381446.

10. Gurusiddaiah, S., Weller, D. M., Sarkar, A., and Cook, R. J. 1986. Characterization of an 
antibiotic produced by a strain of Pseudomonas fluorescens inhibitory to Gaeumannomyces graminis var. tritici and Pythium spp. Antimicrob. Agents Chemother. 29: 488-495.

11. Haygood, R. A., and Mazur, A. R. 1990. Evaluation of Gliocladium virens as a biocontrol agent of dollar spot on bermudagrass. (Abstr.) Phytopathology 80:435.

12. Haynes, W. C., Stodola, F. H., Locke, J. M., Pridham, T. G., Conway, H. F., Sohns, V. E., and Jackson, R. W. 1956. Pseudomonas aureofaciens Kluyver and phenazine $\alpha$-carboxylic acid, its characteristic pigment. J. Bacteriol. 72:412-417.

13. Iwasa, T., Higashide, E., Yamamoto, H., and Shibata, M. 1971. Production and biological properties of validomycins A and B. J. Antibiot. 24:107-113.

14. Knuppel, P. C., Lantzsch, R., and Wellweber, D. 1992. Synthesis of fungicidal phenylpyrroles. Pages 405-413 in: Synthesis and Chemistry of Agrochemicals III. D. R. Baker, J. G. Fenyes, and J. J. Steffens, eds. ACS Symposium Series No. 504, American Chemical Society, Washington, DC.

15. Lo, C.-T., Nelson, E. B., and Harman, G. E. 1996. Biological control of turfgrass diseases with a rhizosphere competent strain of Trichoderma harzianum. Plant Dis. 80:736-
741.

16. Melvin, B. P. 1991. Biological and cultural management of summer patch and necrotic ring spot. Ph.D. diss. Michigan State University, East Lansing.

17. Nelson, E. B., and Craft, C. M. 1991. Introduction and establishment of strains of Enterobacter cloacae in golf course turf for the biological control of dollar spot. Plant Dis. 75:510-514.

18. Nelson, E. B., and Craft, C. M. 1992. Suppression of dollar spot on creeping bentgrass and annual bluegrass turf with compostamended topdressings. Plant Dis. 76:954-958.

19. Nyfeler, R., and Ackerman, P. 1992. Phenylpyrroles, a new class of agriculture fungicides related to the natural antibiotic pyrrolnitrin. Pages 395-404 in: Synthesis and Chemistry of Agrochemicals III. D. R. Baker, J. G. Fenyes, and J. J. Steffens, eds. ACS Symposium Series No. 504, American Chemical Society, Washington, DC.

20. Sarniguet, A., and Lucas, P. 1992. Evaluation of populations of fluorescent pseudomonads related to decline of take-all on turfgrass. Plant Soil 145:11-15.

21. Thomashow, L. S., and Weller, D. M. 1988. Role of phenazine from Pseudomonas fluorescens in biological control of Gaeumannomyces graminis var. tritici. J. Bacteriol.
170:3499-3508.

22. Thomashow, L. S., Weller, D. M., Bonsall, R. F., and Pierson, L. S. 1990. Production of the antibiotic phenazine-1-carboxylic acid by fluorescent Pseudomonas species in the rhizosphere of wheat. Appl. Environ. Microbiol. 56:908-912.

23. Turner, J. M., and Messenger, A. J. 1986. Occurrence, biochemistry and physiology of phenazine pigment production. Adv. Microbiol. Physiol. 27:211-275.

24. Umezawa, $\mathrm{H}$, Okami, $\mathrm{Y}$, Hashimoto, $\mathrm{T}$, Suhara, Y., Hamada, M., and Takeuchi, T. 1965. A new antibiotic, kasugamycin. J. Antibiot. 18A:101-103.

25. Vargas, J. M., Jr. 1981. Management of turfgrass diseases. Burgess Publishing Co., Minneapolis, MN.

26. Warren, C. G., Sanders, P., and Cole, H. 1974. Sclerotinia homoeocarpa tolerance to benzimidazole configuration fungicides. Phytopathology 64:1139-1142.

27. Weller, D. M., and Cook, R. J. 1983. Suppression of take-all of wheat by seed treatments with fluorescent pseudomonads. Phytopathology 73:463-469.

28. Ypema, H. L., and Gold, R. E. 1999 Kresoxim-methyl: Modification of a naturally occurring compound to produce a new fungicide. Plant Dis. 83:4-19. 